\title{
Indonesian Coconut Competitiveness In International Markets
}

\section{Heriyanto Heriyanto *}

Department of Agribusiness, Faculty of Agricultural, Universitas Islam Riau, Indonesia

\section{Detri Karya}

Departemen of Management, Faculty of Economics, Universitas Islam Riau, Indonesia

\section{Asrol Asrol}

Department of Agribusiness, Faculty of Agricultural, Universitas Islam Riau, Indonesia

*Corrosponding author’s Email: heriyanto@agr.uir.ac.id

Peer-review under responsibility of $4^{\text {th }}$ Asia International Conference 2018 editorial board (http://www.utm.my/asia/our-team/) (C) 2018 Published by Readers Insight Publisher, lat 306 Savoy Residencia, Block 3 F11/1,44000 Islamabad. Pakistan, info@ readersinsight.net

This is an open access article under the CC BY-NC-ND license (http://creativecommons.org/licenses/by-nc-nd/4.0/). 


\section{Research High I ights}

The results showed that during the period of 2005-2016, the development of supply and demand are relatively unstable and likely to rise. ISP values during the period of 2005-2016 has the value positive that shows that Indonesia is a country exporting coconut and belongs into the categories of very mature in the international market, indicated by the average value of the ISP of 1.00. The value of the RCA during the period of 2005-2016 have a value above 1 indicating that Indonesia Coconut has a comparative advantage for the commodity. While the analysis results CMS during the period of 2005-2016 based on the four effects shows that the competitiveness of coconut Indonesia influenced by standard growth effects and effect distribution where the coconut export growth in Indonesia is affected by the growth of coconut import world.

\section{Research Objectives}

In general, this study aims to analyze the Competitiveness of Indonesian Coconut Exports in International Markets, specifically aimed at analyzing the position and competitiveness of Indonesian coconut commodities on the international market..

\section{Methodology}

His study uses secondary data is data that is in the form of time series data for 10 years i.e. year 2005 - 2015. Secondary data collected for this research, namely statistics data: data on production, land area data, data export and import countries and Indonesia Coconut pesain namely the Philippines, Malaysia and Sri Lanka. This data is obtained from the relevant agencies, including: the Central Bureau of statistics (BPS), the International Trade Center which traces back through the internet network, the United Nation's Trade, the Directorate General of Plantations of the Republic of Indonesia, the trading Watchdog Agency Commodity futures, and the Food and Agriculture Organization (FAO), Industry data and Information Center of the Ministry of industry of Indonesia. Methods of data analysis using 


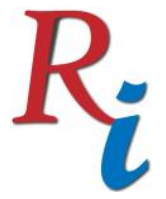

\section{Asia Proceedings of Social Sciences (APSS) \\ www.readersinsight.net/APSS}

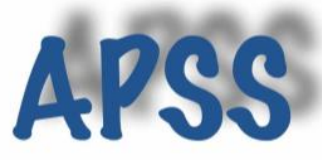

Trade Specialization Index (TSI), the analysis Revealed Comparative Advantage (RCA), and the Constant Market Share analysis (CMS) (Adi, Putra, I, Ketut \& Aswitari, Luh, 2015; Anggit, 2012; Da, 2014; Fitriana, 2014; Hagi, 2014; Hasibuan A.M, 2011; Kania, 2012; Kusuma, Rahma \& Firdaus, 2015; Marlinda, 2008; Meryana, 2007; Nusyirwan \& Bakce, 2017; Ogi, Suparsa \& Martini, Dewi, 2016; Prasetyo \& Marwanti, 2017; Ratna Sari \& Tety, 2017; Satryana, Made \& Karmini, 2016; Setiawan \& Hartono, Slamet Suryantini, 2014; Syahputra, Tarumun, \& Yusri, 2014; Utami \& Yulianto, 2018; Zuhdi \& Suharno, 2015; Zuliastri, Rindayati, \& Asmara, 2015)

\section{Results}

Based on the results of the analysis of Trade Specialization Index (TSI), the TSI is positive value and approaching +1 are Indonesia and the Philippines with the average value of each 1.00 and 0.97. This shows that Indonesia and the Philippines have strong competitiveness or a tendency to have a position as an exporting country belongs to the coconut into the categories of very ripe coconut trade in the world. The results of the analysis of competitiveness shows: based on the analysis Revealed Comparative Advantage (RCA), during the period of 2005-2016 Countries that have comparative advantages/strong competitiveness for commodity coconut is the Philippines and Indonesia. Meanwhile, Malaysia, Srilanka, India, Brazil, and Singapore do not have competitiveness. Based on the results of the analysis of the Constant Market Share (CMS) shows that the competitiveness of Indonesia's much influence by standard growth effect an effect the distribution market. It is demonstrated by average growth rate thresholds for 12 years, namely the period 2005-2016 shows a positive value where this means Indonesia coconut export growth is affected by the growth of the world coconut imports.

\section{Findings}

Trade Specialization Index (TSI) P values during the period of 2005-2016 has the value positive that shows that Indonesia is a country exporting coconut and belongs into the categories of very mature in international markets. RCA value have a value above 1 indicating that Indonesia Coconut has a comparative advantage for the commodity. While the 


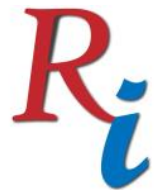

\section{Asia Proceedings of Social Sciences (APSS) \\ www.readersinsight.net/APSS}

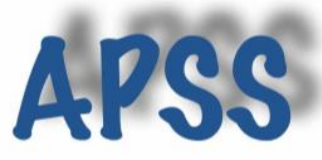

analysis results CMS during the period of 2005-2016 based on the four effects shows that the competitiveness of coconut Indonesia influenced by standard growth effects and effect distribution where the coconut export growth in Indonesia is affected by the growth of coconut import world

\section{Acknowledgement}

The Biggest thanks to all colleagues during the data collection and the parties involved in this research and the Universitas Islam Riau who permitted field observation, and hopefully this journal can be useful as it should.

\section{References}

Adi, Putra, I, Ketut, B. M., \& Aswitari, Luh, P. (2015). Analisis Daya Saing Dan FaktorFaktor Yang Mempengaruhi Ekspor Kayu Lapis Indonesia Ke Jepang. EJurnal Ekonomi Pembangunan Universitas Udayana, 4(6), 608-745.

Anggit, R. (2012). Analisis Daya Saing Crude Palm Oil (CPO) Indonesia di Pasar Internasional. Jurnal Fakultas Pertanian, Universitas UPN "Veteran," 9(1), $125-133$.

Fitriana, N. (2014). Analisis Daya Saing Ekspor Biji Kakao (Cocoa Beans) Indonesia di Pasar Internasional.

Hagi. (2014). Analisis Daya Saing Ekspor Minyak Sawit Indonesia dan Malaysia di Pasar Internasional.

Hasibuan A.M. (2011). Analisisi Kinerja dan Daya Saing Perdagangan Biji Kakao dan Produk Kakao Olahan Indonesia di Pasar Internasional. Jurnal Agribisnis, 3(1), 57-70.

Kania, R. (2012). Analisis Daya Saing Ekspor Lada Indonesia di Pasar Internasional. Skripsi Fakultas Pertanian, Universitas Siliwangi, Tasikmalaya. (Tidak dipublikasikan).

Marlinda, B. (2008). Analisis Daya Saing Lada Indonesia di Pasar Internasional. Skripsi Fakultas Pertanian, Institut Pertanian Bogor, Bogor.

Meryana. (2007). Analisis Daya Saing Kopi Robusta Indonesia di Pasar Kopi Indonesia. Skripsi Fakultas Pertanian, Institut Pertanian Bogor, Bogor. (Tidak 


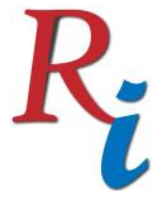

\section{Asia Proceedings of Social Sciences}

(APSS)

www.readersinsight.net/APSS

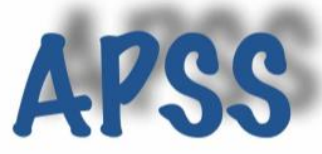

dipublikasikan).

Nusyirwan, R., \& Bakce, D. (2017). Pengaruh Faktor-Faktor Internal dan Eksternal Terhadap Pengembangan Industri Kelapa di Kabupaten Indragiri Hilir, XXXIII, 37-44.

Ogi, Suparsa, I. P., \& Martini, Dewi, N. P. (2016). Analisis Daya Saing Ekspor Komoditi Kepiting Provinsi Bali. E-Jurnal Ekonomi Pembangunan Universitas Udayana, 5(6), 652-728.

Prasetyo, A., \& Marwanti, S. (2017). Keunggulan Komparatif dan Kinerja Ekspor Minyak Sawit Mentah Indonesia di Pasar Internasional, 35(2), 89-103.

Ratna Sari, D., \& Tety, E. (2017). Analisis Daya Saing Ekspor Kopi Indonesia Di Pasar Dunia. Jurnal Ilmiah Ekonomi dan Bisnis Universitas Lancang Kuning, 14(1), $20-35$.

Satryana, Made, H., \& Karmini, N. (2016). Analisis Daya Saing Ekspor Teh Indonesia Ke Pasar ASEAN Periode 2004-2013. E-Jurnal Ekonomi Pembangunan Universitas Udayana, 5(5), 530-651.

Setiawan, K., \& Hartono, Slamet Suryantini, A. (2014). Analisis Daya Saing komoditas kelapa di Kabupaten Kupang. Jurnal Agritec, 34(1), 88-93.

Syahputra, Y. R., Tarumun, S., \& Yusri, J. (2014). ). Analisis Daya Saing Ekspor Karet Alam (Natural Rubber) Indonesia di Pasar Internasional. Jurnal Online Mahasiswa (JOM) Bidang Pertanian, 1(2), 1-9.

Utami, T. A., \& Yulianto, E. (2018). Analisis Daya Saing Ekspor Biji dan Produk Olahan Kakao Indonesia ( Periode Tahun 2012-2016 ), 62(2), 11-20.

Zuhdi, F., \& Suharno, S. (2015). Analisis Daya Saing Ekspor Kopi Indonesia Dan Vietnam Di Pasar ASEAN. E-jurnal Habitat Department of Social Economy, Faculty of Agriculture, 26(3), 152-162.

Zuliastri, F., Rindayati, W., \& Asmara, A. (2015). Jurnal Ekonomi dan Kebijakan Pembanguan, hlm. 113-134 Vol 2 No 2. Jurnal Ekonomi dan Kebijakan Pembanguan, 2(2), 113-134. 